\title{
Spunbonded Polypropylene Fabric Covers Can Enhance Cranberry Establishment and Production
}

\author{
Kim D. Patten ${ }^{1}$ and John Wang ${ }^{2}$ \\ Washington State University, Long Beach Research and Extension Unit, Long \\ Beach, WA 98631 \\ Additional index words. Vaccinium macrocarpon, row covers
}

Low levels of available carbohydrates early in the growing season are important in limiting fruit set in cranberries (Birrenkott et al., 1991). Stang (1991) and Stang et al. (1991) investigated the use of fabric covers to enhance early season carbohydrate levels and fruit set in cranberries in Wisconsin. They reported that covers increased plant chlorophyll content, photosynthesis, and upright growth in new bogs. There was an inconsistent or negative effect, however, on fruit set and yield in bearing bogs. Cranberries grown in areas with a cool maritime climate and an extended flowering period might benefit more from placing rowcovers early than would those grown in the continental climate of Wisconsin. Fabric covers also may be beneficial in cooler climates to hasten vining-over of new bogs or to increase production of established bogs.

New planting. To determine the effect of fabric covers on new bogs, 'Stevens' cranberry vines were planted 15 Apr. 1990 in sandy loam soil at Long Beach, Wash. Spunbonded polypropylene fabric $\left(21 \mathrm{~g} \cdot \mathrm{m}^{-2}\right)$ (KimberlyFarms,Roswell,Ga.)covered young vines from 6 June to 9 Sept. Plot size was $15 x$ $15 \mathrm{~m}$. Covers were held in place with metal pipes along the perimeters. There were four replications each of covered and noncovered plots in a randomized complete block design. All plots received identical cultural practices. Plots were rated for the amount of ground covered by vine growth (vining-over) on 31 Aug. 1990 and 24.Aug. 1991, and for incidence of red leaf spot (Exobasidium rostrojii Nannf.) on 10ct. 1990. In Dec. 1990, a 15-m transect was laid within each plot along a line where the vines had been disked in at planting. At six randomly selected locations along that line, a $0.1 \times 0.33-\mathrm{m}$ area of vines was harvested and fresh weight recorded. Covers improved vining-over of a new planting the first

Received for publication 24 May 1993. Accepted for publication 7 July 1993. H/LA paper no. 93-08. Project no. 6090, College of Agriculture and Home Economics Research Center, Washington State Univ., Pullman. The cost of publishing this paper was defrayed in part by the payment of page charges. Under postal regulations, this paper therefore must be hereby marked advertisement solely to indicate this fact.

'Associate Horticulturist.

${ }^{2}$ Research Technician. year and there was a trend for increased growth; however, covers also increased the incidence of red leaf spot disease (Table 1). In Sept. 1990, Mycosphaerella nigro-maculan Shear (black spot disease) invaded the stem and leaf lesions of the red leaf spot disease, causing considerable vine dieback. As a consequence, by August of the second year, there was no difference in vining-over between treatments.

Established planting. Timing of prebloom fabric application was evaluated in 1991 and 1992 on an established 'McFarlin' cranberry bed. In one experiment, vines were covered from 17 Apr. to 8 May 1991. Plot size was 1.5 $\times 3 \mathrm{~m}$, with four replications per treatment. In another area of that same bed, covers were in place from 9 to 20 May1991. Plot size was 1.5 $\times 3 \mathrm{~m}$, with nine replications per treatment. In 1992, vines were covered from 14 to 29 Apr. Plot size was $1.5 \times 3 \mathrm{~m}$, with six replications per treatment. All of the above experiments were arranged in a randomized complete block with noncovered ots serving as controls. For the 1992 experiment, new upright growth was measured on 11 May, and the percentage of flowers that had already bloomed was measured on 19 June. Fruit set for 25 flowering uprights per plot was obtained both years. Canopy and soil temperatures were measured with a digital thermometer at selected times to obtain representative data from warm and cold days. Established 'McFarlin' and 'Crowley' cranberry vines also were covered postanthesis (7 July 1990); covers were removed 5 Sept. 1990. There were five replications in a randomized complete block design per cultivar for covered and noncovered plots. Plot size was $1.5 \times 3 \mathrm{~m}$. Yield was taken in 1990 and 1991 for 'McFarlin', but only in 1990 for 'Crowley', using a Furford dry harvester (1.2 $\times 3$-m swath along the length of the plot).

Coverage for 3 weeks ( $=1.5$ to 2 months before full bloom) increased yield in 1991 (73 $\mathrm{g} \cdot \mathrm{dm}^{-2}$ treated vs. $41 \mathrm{~g} \cdot \mathrm{dm}^{-2}$ nontreated, $P=$ 0.02 ). There was no carry-over effect on yield in the following year (data not shown). Covering plants at a slightly later developmental stage (9-20 May) in 1991 had no significant effect on yield $\left(61 \mathrm{~g} \cdot \mathrm{dm}^{-2}\right.$ treated vs. $66 \mathrm{~g} \cdot \mathrm{dm}^{-2}$ nontreated). 'None of the pre-anthesis cover treatments affected fruit set (data not shown). In 1992, fabric covers promoted early upright growth (growth by 11 May, $19 \mathrm{~mm}$ treated vs. $1 \mathrm{~mm}$ nontreated, $P \leq 0.001)$ and flowering (37\% treated vs. $10 \%$ nontreated for out-ofbloom flowers on 19 June, $P \leq 0.001)$, but did not affect yield $\left(245 \mathrm{~g} \cdot \mathrm{dm}^{-2}\right.$ treated vs. 228 $\mathrm{g} \cdot \mathrm{dm}^{-2}$ nontreated). Postanthesis placement of fabric covers suppressed yield in the year of coverage (44 $\mathrm{g} \cdot \mathrm{dm}^{-2}$ treated vs. $121 \mathrm{~g} \cdot \mathrm{dm}^{-2}$ nontreated for 'Crowley', $P \leq 0.05 ; 34 \mathrm{~g} \cdot \mathrm{dm}^{-2}$ treatedvs $73 \mathrm{~g} \cdot \mathrm{dm}^{-2}$ nontreated for 'McFarlin', $P \leq 0.05)$ and the subsequent year $\left(60 \mathrm{~g} \cdot \mathrm{dm}^{-2}\right.$ treated vs. $245 \mathrm{~g} \cdot \mathrm{dm}^{-2}$ nontreated for 'McFarlin', $P \leq 0.001$ ).

Canopy temperature was 3 to $5 \mathrm{C}$ warmer for covered plots during cool days (15C) and 10 to $12 \mathrm{C}$ warmer during warmer days (20C). Soil temperature at $1400 \mathrm{HR}$ at a 4 -cm depth on 20C days was 5C warmer in covered plots for the new planting and $2 \mathrm{C}$ warmer for an established planting compared to noncovered plots.

Covering cranberry plants with fabric enhanced flowering, accelerated new vine growth, and, in some cases, increased yield. Application timing influenced the results. For bearing bogs, the influence of fabric covers on yield was not consistent or great enough to warrant their expense. The covers' positive effects on flowering may have been counterbalanced by reduced light levels under them. Using covers to establish new beds rapidly in cool climates might be justified. Their use, however, creates a favorable environment for inoculation and infection by certain foliar diseases and would require an aggressive disease prevention program.

\section{Literature Cited}

Birrenkott, B.A., C.A. Henson andE.J. Stang. 1991. Carbohydrate levels and the development of fruit in cranberry. J. Amer. Soc. Hort. Sci. 116:174-178.

Stang, E.J. 1991. Covers on cranberries: A positive response? Wisconsin Cranberry School 1991 Proc. p. 4-7.

Stang, E.J., J. Klueh, and B.A. Birrenkott. 1991. Spunbonded fabric covers suggest possibilities to alter early season growth and fruiting in cranberry. HortScience 26:71.

Table 1. Polypropylene fabric cover influence on the establishment of a new 'Stevens' cranberry planting.

\begin{tabular}{|c|c|c|c|c|}
\hline \multirow[b]{2}{*}{ Covered } & \multicolumn{2}{|c|}{ Vining-over rating ${ }^{2}$} & \multirow{2}{*}{$\begin{array}{c}\text { Vine fresh } \\
\text { wt }(\mathrm{g}) \text { along } \\
0.1 \times 2-\mathrm{m} \text { transect } \\
(\text { Dec. } 1990)\end{array}$} & \multirow{2}{*}{$\begin{array}{l}\text { Red leaf spot } \\
\text { incidence } \\
\text { (Oct. 1990) }\end{array}$} \\
\hline & 31 Aug. 1990 & 27 Aug. 1991 & & \\
\hline Yes & 7.6 & 6.0 & 163 & 5.9 \\
\hline No & $\begin{array}{r}5.6 \\
* * *\end{array}$ & 6.8 & 116 & 2.1 \\
\hline Significance & & NS & NS & \\
\hline
\end{tabular}

${ }^{2}$ Vining-over rating $1-9,1=$ no coverage, $9=$ high vine vigor and good coverage.

Red leaf spot coverage, $1=$ none; $9=100 \%$ vine coverage.

${ }^{* * *, N s}$ Significant $\mathrm{F}$ test at $P \leq 0.001$ or nonsignificant, respectively. 